\title{
Ecological Effects of Roads on the Plant Diversity of Coastal Wetland in the Yellow River Delta
}

\author{
Yunzhao Li, ${ }^{1,2}$ Junbao Yu, ${ }^{1}$ Kai Ning, ${ }^{1,2}$ Siyao Du, ${ }^{3}$ Guangxuan Han, ${ }^{1}$ Fanzhu Qu, ${ }^{1,2}$ \\ Guangmei Wang, ${ }^{1}$ Yuqin Fu, ${ }^{1,2}$ and Chao Zhan ${ }^{1,2}$ \\ ${ }^{1}$ Key Laboratory of Coastal Zone Environmental Processes and Ecological Remediation, \\ Yantai Institute of Coastal Zone Research (YIC), Chinese Academy of Sciences (CAS) and Shandong Provincial Key Laboratory of \\ Coastal Zone Environmental Processes, YICCAS, Yantai, Shandong 264003, China \\ ${ }^{2}$ University of Chinese Academy of Sciences, Beijing 100049, China \\ ${ }^{3}$ College of Environmental Science and Engineering, Ocean University of China, Qingdao, Shandong 266100, China
}

Correspondence should be addressed to Junbao Yu; junbao.yu@gmail.com

Received 22 February 2014; Revised 14 March 2014; Accepted 14 March 2014; Published 31 March 2014

Academic Editor: Hong-bo Shao

Copyright (C) 2014 Yunzhao Li et al. This is an open access article distributed under the Creative Commons Attribution License, which permits unrestricted use, distribution, and reproduction in any medium, provided the original work is properly cited.

\begin{abstract}
The 26 sample sites in 7 study plots adjacent to asphalt road and earth road in coastal wetland in the Yellow River Delta were selected to quantify plant diversity using quadrat sampling method in plant bloom phase of July and August 2012. The indice of $\beta_{T}$ and Jaccard's coefficient were applied to evaluate the species diversity. The results showed that the plant diversities and alien plants were high in the range of $0-20 \mathrm{~m}$ to the road verge. There were more exotics and halophytes in plots of asphalt roadside than that of earth roadside. However, proportion of halophytes in habitats of asphalt roadsides was lower than that of earth roadside. By comparing $\beta$-diversity, there were more common species in the asphalt roadsides than that in the earth roadsides. The similarity of plant communities in studied plots of asphalt roadsides and earth roadsides increased with increasing the distance to road verge. The effect range of roads for plant diversity in study region was about $20 \mathrm{~m}$ to road verge. Our results indicate that the construction and maintenance of roads in wetland could increase the plant species diversities of communities and risk of alien species invasion.
\end{abstract}

\section{Introduction}

Roads are common artificial infrastructures, but high density roads rarely appear in wetlands. However, the study interests of road ecology in the wetland are growing [13]. Construction and maintenance of roads have modified the natural wetland landscape and might result in many ecological effects (or ecological risks) [4-6]. Generally, there are six primary ecological effects of roads, that is, (1) habitat loss [7], (2) disturbance [8,9], (3) corridor [10, 11], (4) mortality [12], (5) barrier [13], and (6) behavior modification [14-16]. The ecological effects of roads can be divided into effects in construction period and short term effects and long term effects in operation period $[17,18]$. Therefore, it is difficult to evaluate accurately ecological effects of road on ecosystem because of comprehensive results [19-22]. The roads construction and existence have shown deleterious effects on a variety of ecosystems $[1,23,24]$ and often noted by ecologists for their far-reaching negative consequences to ecosystem structures and flows [10, 22, 24-27]. Meanwhile, some road effects are beneficial to ecosystems though they are hard to confirm [22]. For example, ecologists have found that the positive feedbacks, for example, regional climate change, and the amount of forest fragmentation and deforestation directly related to the construction of roads $[28,29]$. Actually, it is true that roads and roads edges provide resources for some species, particularly small mammals and insects $[7,17$, $24]$. In some cases, roads were found to have been acted as essential corridors for survival, movement, and propagation $[7,24,30]$. The wetland vegetation, one of the three most important elements of wetlands [31,32], is greatly affected by the disturbance of road. The previous studies in the YRD reported that the high species richness and biodiversity were observed adjacent to the road verge [33]. Besides the distance from the road verge, the width, noise, vehicle traffic levels of road, and highway density also could influence the plant 


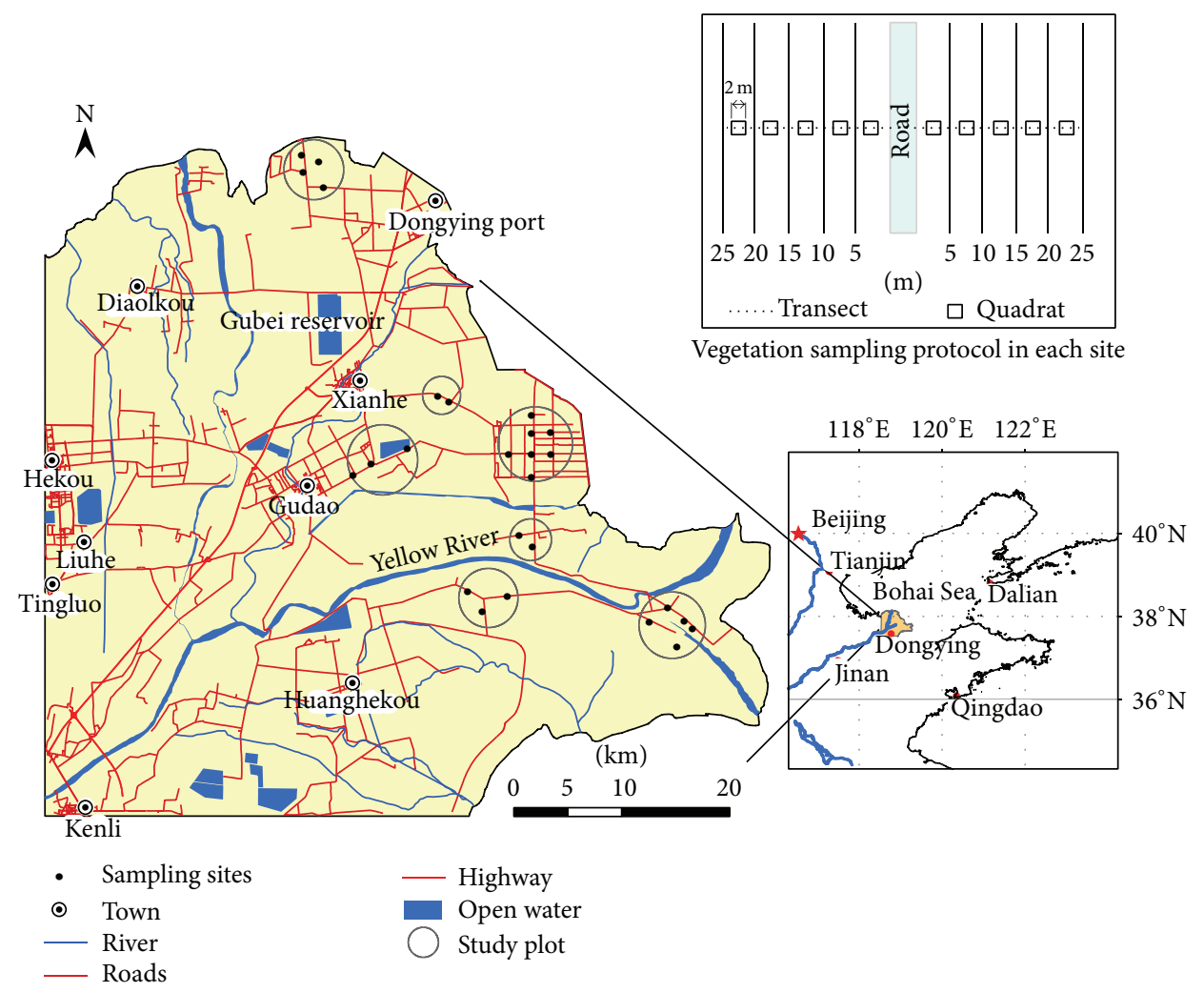

Figure 1: Location of the study area and sampling sites in the Yellow River Delta.

community anyway $[4,24,34]$. In addition, the natural wetland landscape and the water-salt migration in coastal wetland could be changed by road, which might result in changes of the environment of vegetation growth $[23,35$, 36]. Previous studies reported that there was heavy metals accumulation in road verge soils, which might influence plants adjacent to road indirectly [37-40]. It was also believed that construction and maintenance of roads might alter nutrient levels, bulk density, and moisture of soils and led to a high soil concentration of nitrogen at roadside verges $[41,42]$. Roads altered flows of materials in the landscape and changed levels of available resources, such as water, light, and nutrients of ecosystems [24], and thus affected the plant communities. Therefore, it could not be affirmed that the road effects are positive or not briefly before evaluating the road effects objectively as much as possible. To implement this objective, the YRD wetland was selected as a suitable place to evaluate the effects of road on vegetation distribution in coastal wetlands because the high density of roads was constructed for oil exploitation.

There are several types of roads, for example, asphalt road, cement road, and earth road for oil exploitation in the YRD wetland which is a short-formed and protogenous ecosystem with various kinds of wetland plants [43], resulting in dividing the wetland into patches. Our assumption is that the wetland plants might be impacted by different kinds of roads, resulting in differences of community composition and biodiversity appearing in verges of the different types of road. With this assumption, the wetland plant communities beside the road verges of asphalt road and earth road which were representative road types in the study region were surveyed using quadrat sampling method in plant bloom phase. The objectives of this study are to reveal (1) the composition changes of plant communities in the habitats adjacent to the asphalt roads and earth roads and (2) how the plant biodiversity is affected by roads.

\section{Materials and Methods}

2.1. Description of the Study Area. The study area is located in the YRD, eastern China (Figure 1). The regional climate is a temperate semihumid continental monsoon climate and the average annual precipitation in the study area is $530-630 \mathrm{~mm}$, of which $70 \%$ is in the summer $[44,45]$. Evaporation is strong and the ratio of evaporation to precipitation is about $3: 1$ [46]. The YRD is a flat floodplain with a plain slope of 0.0001 and an area less than $10 \mathrm{~m}$ in elevation [47]. Swamp and salt marsh are widespread in the study area and the predominant natural wetland plants are Phragmites australis, Tamarix chinensis, and Suaeda salsa. The oil exploitation is the major human activity in the natural wetland region where there are few settlements. There was about $2035.5 \mathrm{~km}$ of asphalt road built for oil exploitation from 1963 to 2002 in the YRD.

2.2. Sampling Sites and Methods. The 26 sample sites in 7 study plots adjacent to asphalt road and earth road in coastal wetlands were selected to quantify plant communities using 
quadrat sampling method in plant bloom phase of July and August 2012 (Figure 1). The selected study plots were plain and far from human settlements and seashore as well as the Yellow River to weaken the impacts from slope, irrelevant human activities, the sea and river. By referring to the speciesarea curve established by Zeng et al. [33], the $2 \mathrm{~m} \times 2 \mathrm{~m}$ quadrats were adopted for sampling. Two transects with opposite directions perpendicular to a selected road were made in each site. The five quadrats were arranged at $0-5 \mathrm{~m}$, 5-10 $\mathrm{m}, 10-15 \mathrm{~m}, 15-20 \mathrm{~m}$, and $20-25 \mathrm{~m}$ to the road verge in each transect (Figure 1). The presence, name, coverage, number, and dominance of all vascular plants were surveyed and recorded at each quadrat.

2.3. Data Analysis. To reveal the composition of wetland plant communities in the road verges, the proportion of halophytes and exotics in all plants was calculated. The occurrence frequencies of all recorded plants were compared to determine the most common species.

$\beta$-diversity, which is the variation in species composition among localities [48], was used to detect changes of communities in studied plots with distance to road verges. The indice of $\beta_{T}$ which was described by Wilson and Shmida [49] was adopted to implement in this study:

$$
\beta_{T}=\frac{[g(H)+l(H)]}{2 \alpha},
$$

where $g(H)$ and $l(H)$ are the numbers of species gained and lost, respectively, along a (habitat) gradient and $\alpha$ is the average number of species found within the community samples.

The Jaccard's coefficient $(J)$ which may be expressed in several ways [50] was used to compare the similarity of plants composition among localities:

$$
J=\frac{c}{a+b-c},
$$

where $c$ is the number of species common to both sites, $a$ is the number of species in the first plot (with high species), and $b$ is the number of species in the second plot (with low species).

In addition, independent-sample Student's $t$-test was used to evaluate the effects of regional disparity on number of species applying the software of SPSS 18.0 [51].

\section{Results and Discussion}

3.1. Comparison of Plant Species in the Asphalt Roadside and Earth Roadside. A total of 48 plant species with an incidence of $10-90 \%$ for eighteen species were found within $25 \mathrm{~m}$ to the roadsides during investigation (Table 1 ). The observed species belonged to 22 families. The best-represented families were Gramineae (8), Compositae (7), Chenopodiaceae (5), and Leguminosae (4). The most common species were Phragmites australis (Cav.) Trin. ex Steud., Suaeda salsa (L.) Pall., Tamarix chinensis Lour., Sonchus oleraceus L., Artemisia argyi Levl. et Van., and Imperata cylindrica (L.) Beauv.Eight species $(17 \%)$ were identified as exotics and $36(75 \%)$ as halophytes. The most abundant life form was herb, of which

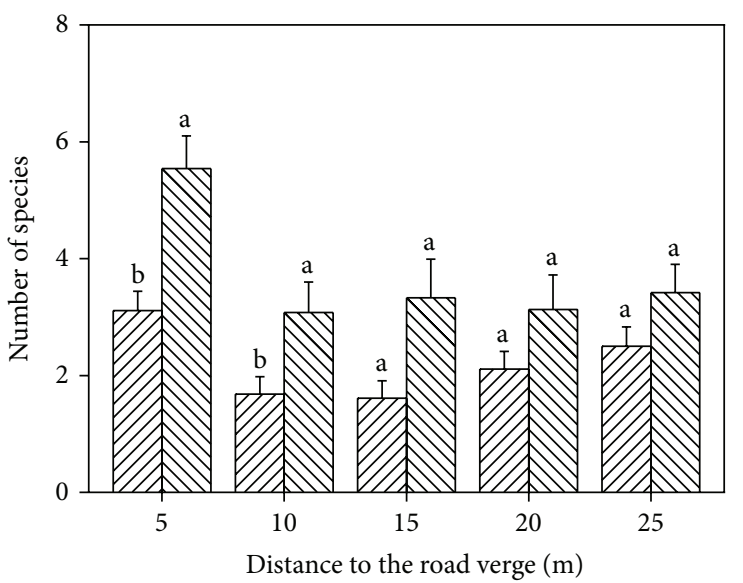

$\square 77$ Earth road
$\square I D$ Asphalt road

FIgURE 2: Number of species in plots of asphalt roadsides and earth roadsides. Letters above error bar of each column indicate significant difference at the $P<0.05$ level for Student's $t$-test.

40 species $(83 \%)$ were observed. The total observed plant species in this study was about half of previous identified results (100 species) in the same region [33, 52], because of the attributions of the different sampling sites location, roadside conditions, and anthropogenic impacts. The sampling sites in the previous study mainly located in both sides of truck road in the central part of the YRD where the conditions of soil and freshwater for plant were much better than those in present plots. In addition, some special plants were purposefully planted in truck road verges to maintain the roadbed and the high vehicle flow increased the spread of exotics, resulting in higher alien plants in previous study $[33,52]$ than this study. Agreeing with previous studies [33, 52, 53], the herbaceous plants with high proportion of halophytes were high and ligneous plants were few in the communities of roadsides in the YRD (Table 1).

The mean value of species in the asphalt roadside was larger than that in the earth roadside regardless of distance from road verges (Figure 2). The differences of number of species were significant within $0-10 \mathrm{~m}$ from road edge between the earth road and the asphalt road (Figure 2). Generally, the number of exotics decreased with distance increase to the road edge and those in asphalt roadside were greater than that in earth roadside regardless of distance from road verge (Figure 3). 24 (80\%) and 30 (77\%) halophytes were found in the earth road verge and the asphalt road verge, respectively (Table 1). The number of halophytes in the asphalt roadside was greater than that in the earth roadside. However, the proportion of halophytes in all plant species in the asphalt roadside was smaller than that in the earth roadside (Figure 4). The differences of environment and the anthropogenic activities of the asphalt roadside and earth roadside were mainly responsible for the plant species difference. The truck numbers and human being activities in the asphalt road are much more than the earth road. Based on the survey results, the vehicle traffic flow in asphalt roads 
TABLE 1: List of plant species distributed in roadsides (range of $25 \mathrm{~m}$ ) of the Yellow River Delta during our investigation.

\begin{tabular}{|c|c|c|c|c|c|c|}
\hline Species & Family & $\begin{array}{l}\text { Plots of earth } \\
\text { roadside }\end{array}$ & $\begin{array}{l}\text { Plots of asphalt } \\
\text { roadside }\end{array}$ & Halophyte & Exotics & Life form \\
\hline Amaranthus retroflexus & Amaranthaceae & & $\mathrm{Y}$ & & & Herb \\
\hline Amaranthus viridis & Amaranthaceae & $\mathrm{Y}$ & $\mathrm{Y}$ & $\mathrm{Y}$ & $\mathrm{Y}$ & Herb \\
\hline Rhus typhina L. & Anacardiaceae & & $\mathrm{Y}$ & & $\mathrm{Y}$ & Arbor \\
\hline Apocynum venetum $\mathrm{L}$. & Apocynaceae & $\mathrm{Y}$ & $\mathrm{Y}$ & $\mathrm{Y}$ & & Shrub \\
\hline Metaplexisjaponica (Thunb.) Makino & Asclepiadaceae & $\mathrm{Y}$ & & $\mathrm{Y}$ & & Liane \\
\hline Cynanchum chinense $\mathrm{R}$. Br. & Asclepiadaceae & $\mathrm{Y}$ & $\mathrm{Y}$ & $\mathrm{Y}$ & & Liane \\
\hline Atriplex centralasiatica Iljin & Chenopodiaceae & $\mathrm{Y}$ & & $\mathrm{Y}$ & & Herb \\
\hline Chenopodium hybridum L. & Chenopodiaceae & $\mathrm{Y}$ & & $\mathrm{Y}$ & $\mathrm{Y}$ & Herb \\
\hline Suaeda salsa (L.) Pall. & Chenopodiaceae & $\mathrm{Y}$ & $\mathrm{Y}$ & $\mathrm{Y}$ & & Herb \\
\hline Suaeda glauca (Bunge) Bunge & Chenopodiaceae & $\mathrm{Y}$ & $\mathrm{Y}$ & $\mathrm{Y}$ & & Herb \\
\hline Kochiascoparia (L.) Schrad. & Chenopodiaceae & $\mathrm{Y}$ & & $\mathrm{Y}$ & & Herb \\
\hline Cirsium maackii Maxim. & Compositae & & $\mathrm{Y}$ & & & Herb \\
\hline Taraxacum mongolicum Hand.-Mazz. & Compositae & & $\mathrm{Y}$ & $\mathrm{Y}$ & & Herb \\
\hline Artemisia argyi Levl. et Van. & Compositae & $\mathrm{Y}$ & $\mathrm{Y}$ & $\mathrm{Y}$ & & Herb \\
\hline Scorzonera mongolica Maxim. & Compositae & & $\mathrm{Y}$ & $\mathrm{Y}$ & & Herb \\
\hline Artemisia capillaris & Compositae & $\mathrm{Y}$ & & $\mathrm{Y}$ & & Herb \\
\hline Sonchus oleraceus L. & Compositae & $\mathrm{Y}$ & $\mathrm{Y}$ & $\mathrm{Y}$ & & Herb \\
\hline Dendranthema indicum (L.) Des Moul. & Compositae & $\mathrm{Y}$ & $\mathrm{Y}$ & $\mathrm{Y}$ & & Herb \\
\hline Pharbitis nil (L.) Choisy & Convolvulaceae & & $\mathrm{Y}$ & $\mathrm{Y}$ & & Herb \\
\hline Convolvulus arvensis $\mathrm{L}$. & Convolvulaceae & & $\mathrm{Y}$ & & $\mathrm{Y}$ & Herb \\
\hline Cuscuta chinensis Lam. & Convolvulaceae & $\mathrm{Y}$ & $\mathrm{Y}$ & $\mathrm{Y}$ & $\mathrm{Y}$ & Cancerroot \\
\hline Cyperus rotundus $\mathrm{L}$. & Cyperaceae & $\mathrm{Y}$ & & & & Herb \\
\hline Carex tristachya Thunb. & Cyperaceae & $\mathrm{Y}$ & $\mathrm{Y}$ & & & Herb \\
\hline Ephedra sinica Stapf & Ephedraceae Dumortier & & $\mathrm{Y}$ & $\mathrm{Y}$ & & Herb \\
\hline Imperata cylindrica (L.) Beauv. & Gramineae & $\mathrm{Y}$ & $\mathrm{Y}$ & $\mathrm{Y}$ & & Herb \\
\hline Triarrhena sacchariflora (Maxim.) Nakai & Gramineae & $\mathrm{Y}$ & & & & Herb \\
\hline Setaria viridis (L.) Beauv. & Gramineae & & $\mathrm{Y}$ & $\mathrm{Y}$ & & Herb \\
\hline Chloris virgata $\mathrm{Sw}$. & Gramineae & & $\mathrm{Y}$ & $\mathrm{Y}$ & & Herb \\
\hline Alopecurus aequalis Sobol. & Gramineae & $\mathrm{Y}$ & & & & Herb \\
\hline Phragmites australis (Cav.) Trin. ex Steud. & Gramineae & $\mathrm{Y}$ & $\mathrm{Y}$ & $\mathrm{Y}$ & & Herb \\
\hline Aeluropus sinensis (Debeaux) Tzvel. & Gramineae & $\mathrm{Y}$ & $\mathrm{Y}$ & $\mathrm{Y}$ & & Herb \\
\hline Calamagrostis epigeios (L.) Roth & Gramineae & & $\mathrm{Y}$ & $\mathrm{Y}$ & & Herb \\
\hline Leonurus artemisia (Laur.) S. Y. Hu & Labiatae & & $\mathrm{Y}$ & $\mathrm{Y}$ & & Herb \\
\hline Melilotus officinalis & Leguminosae & & $\mathrm{Y}$ & $\mathrm{Y}$ & $\mathrm{Y}$ & Herb \\
\hline Robinia pseudoacacia & Leguminosae & & $\mathrm{Y}$ & & & Arbor \\
\hline Medicago sativa $\mathrm{L}$. & Leguminosae & $\mathrm{Y}$ & $\mathrm{Y}$ & $\mathrm{Y}$ & & Herb \\
\hline Glycine soja Sieb. et Zucc. & Leguminosae & $\mathrm{Y}$ & $\mathrm{Y}$ & $\mathrm{Y}$ & & Herb \\
\hline Humulus scandens & Moraceae & $\mathrm{Y}$ & $\mathrm{Y}$ & $\mathrm{Y}$ & & Herb \\
\hline Epilobium hirsutum L. & Onagraceae & $\mathrm{Y}$ & $\mathrm{Y}$ & $\mathrm{Y}$ & & Herb \\
\hline Limonium bicolor (Bag.) Kuntze & Plumbaginaceae & $\mathrm{Y}$ & & $\mathrm{Y}$ & & Herb \\
\hline Polygonum orientale L. & Polygonaceae & & $\mathrm{Y}$ & $\mathrm{Y}$ & & Herb \\
\hline Polygonum lapathifolium L. & Polygonaceae & $\mathrm{Y}$ & $\mathrm{Y}$ & & & Herb \\
\hline Portulaca oleracea L. & Portulacaceae & & $\mathrm{Y}$ & $\mathrm{Y}$ & & Herb \\
\hline Salix matsudana & Salicaceae & $\mathrm{Y}$ & $\mathrm{Y}$ & & & Arbor \\
\hline Veronica didyma Tenore & Scrophulariaceae & & $\mathrm{Y}$ & & $\mathrm{Y}$ & Herb \\
\hline Datura stramonium Linn. & Solanaceae & & $\mathrm{Y}$ & $\mathrm{Y}$ & $\mathrm{Y}$ & Herb \\
\hline Tamarix chinensis Lour. & Tamaricaceae & $\mathrm{Y}$ & $\mathrm{Y}$ & $\mathrm{Y}$ & & Shrub \\
\hline Typha orientalis & Typhaceae & $\mathrm{Y}$ & $\mathrm{Y}$ & $\mathrm{Y}$ & & Herb \\
\hline
\end{tabular}



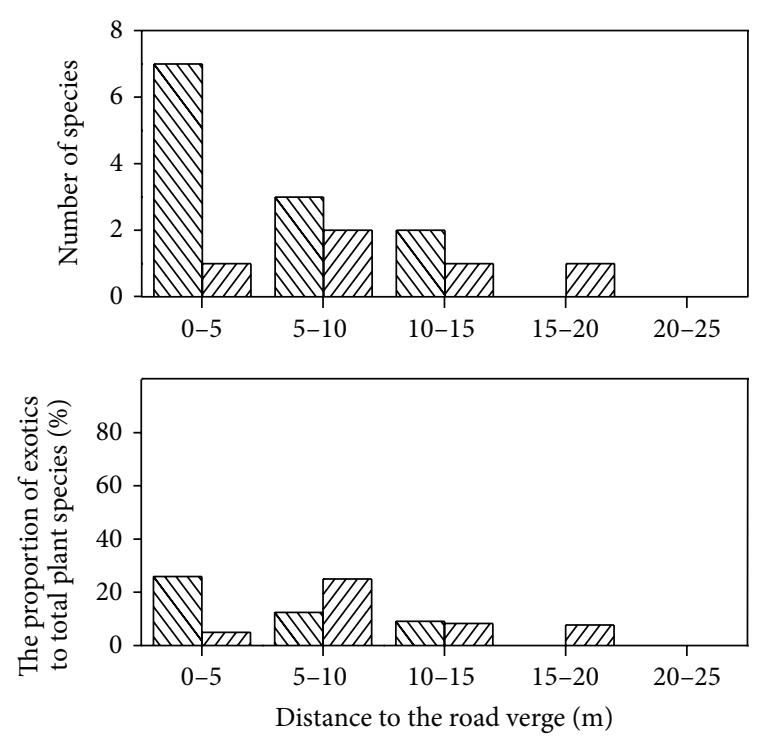

MIV Asphalt road

VII Earth road

FIGURE 3: Number and proportion of alien plant species in plots of asphalt roadsides and earth roadsides.
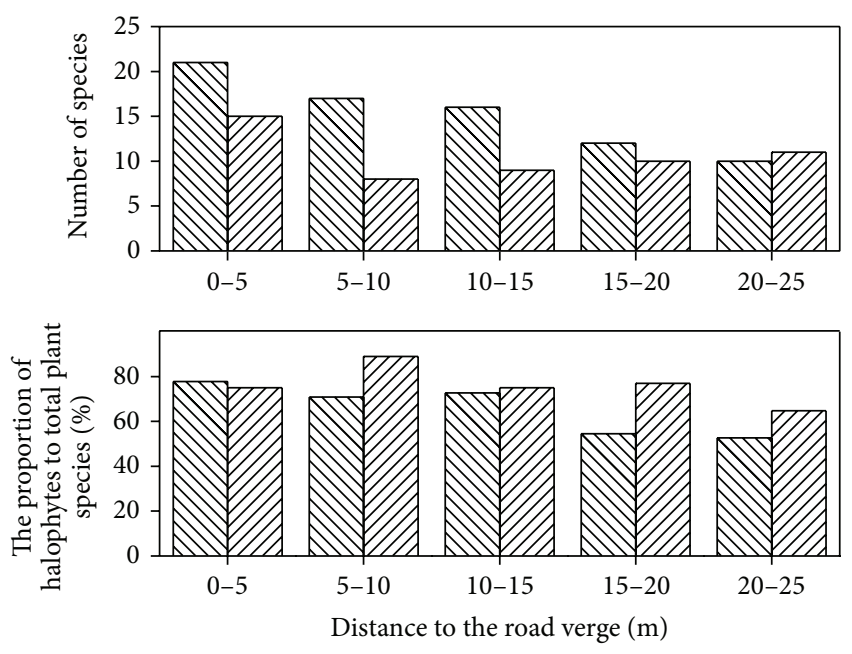

MIV Asphalt road

VII Earth road

FIGURE 4: Number and proportion of halophytes in plots of asphalt roadsides and earth roadsides.

was about 5-8 times higher than that in earth roads, resulting in both the native and the alien plants species in the plots of asphalt roadside being more abundant than that of the earth roadside within a certain distance from sampling site to road (Figures 2 and 3). Furthermore, in order to protect the road and avoid soil-water loss, the vegetation beside the asphalt road was removed first, and then different species of trees and bushes were planted. The removal of habitats and vegetation were soon replaced by new settlers, resulting in more edges in landscape and more niches in communities in the asphalt roadside $[4,18,54]$.

3.2. Effects of Roads on Plant Communities. Roads increased the contacts between plant communities [24] and the anthropogenic activities near roadsides had great impacts on species $[3,4]$. In this study, there were 39 species, of which thirtytwo species $(82 \%)$ were categorized as herbs (Table 1) and were found in 24 sampling transects in the asphalt roadsides, while there were 30 species of which 24 species (80\%) were grassland species and were observed in 28 sampling transects in the earth roadsides (Table 1). Additionally, three and seven alien plants were found near the earth roadside and the asphalt road verge, respectively (Table 1 ). The exotics accounted for no more than $30 \%$ of total plants in both asphalt roadside and earth roadside (Figure 3 ). With the distance to the road edge being increased, the numbers of both saline plants and their proportion in all plants decreased (Figure 4). The results were similar to some previous study results $[33,41,52]$. The road was regarded as dispersal corridor and conduit for vegetation [24, 30, 55-57]. It is believed that roads promoted the dispersal of plant propagules along roadsides [33]. Because of the easy movement of wind, water runoff, and animals by roads, the numerous seeds were carried and deposited along roads by those carriers $[4,58]$. Therefore, plants with high dispersal capacities could preferentially occupy their living spaces along roadsides [56, $59,60]$. Furthermore, the dispersal of native and alien plants was affected directly by the vehicle traffic flow and vectors. Roadsides do provide better growth conditions and are good habitat to vegetation $[61,62]$. Construction and maintenance of road altered the physical and chemical environment of plant communities $[4,5]$. The alterations of light conditions, soil nutrients, and water availability were remunerative for plant communities, thus increasing the survival opportunities for most plants $[61,62]$. Additionally, the elevation of most roadbeds was 1-2 meters higher than that of around wetlands in the YRD, which was a great benefit in salt reducing. The areas of roadsides have become refuges to many nonhalophytes. As a result, both native and alien plant species in roadsides were more abundant than wetland far away from road verge and the proportion of halophytes in the road verges was much lower than in wetland habitats (Table 1 and Figure 4).

3.3. Diversity of Plant Communities in Roadside. The variation of $\beta_{T}$ index showed different patterns between asphalt roadside and earth roadside (Figure 5 and Table 2). The $\beta_{T}$ index of the plant communities decreased gradually with distance to road verge in the spots adjacent to asphalt road. While the variation of $\beta_{T}$ showed an inverse " $N$ " shape with the distance from plant communities to earth roadside, increased the $\beta_{T}$ index in study sites adjacent to earth roadside was larger than that adjacent to asphalt roadside within 20 meters to road verge (Figure 5). The similarity of communities was completely different between the spots of asphalt roadside and earth roadside (Figure 5). The Jaccard's coefficient gradually increased with increase of 
TABLE 2: Matrix of $\beta$-diversity indices measured by numerical data from sampling sites.

\begin{tabular}{|c|c|c|c|c|c|}
\hline $\begin{array}{l}\text { Distance of sampling } \\
\text { sites from road }(\mathrm{m})\end{array}$ & $0-5$ & $5-10$ & $10-15$ & $15-20$ & $20-25$ \\
\hline \multicolumn{6}{|l|}{ Asphalt roadside } \\
\hline $0-5$ & $x$ & 0.4581 & 0.5445 & 0.5751 & 0.5672 \\
\hline $5-10$ & & $\times$ & 0.3361 & 0.5408 & 0.5308 \\
\hline $10-15$ & & & $\times$ & 0.3949 & 0.4494 \\
\hline $15-20$ & & & & $\times$ & 0.3291 \\
\hline $20-25$ & & & & & $\times$ \\
\hline \multicolumn{6}{|l|}{ Earth roadside } \\
\hline $0-5$ & $x$ & 0.4946 & 0.5403 & 0.5342 & 0.5242 \\
\hline $5-10$ & & $\times$ & 0.4639 & 0.6117 & 0.6082 \\
\hline $10-15$ & & & $\times$ & 0.4753 & 0.4689 \\
\hline $15-20$ & & & & $\times$ & 0.2362 \\
\hline $20-25$ & & & & & $\times$ \\
\hline
\end{tabular}

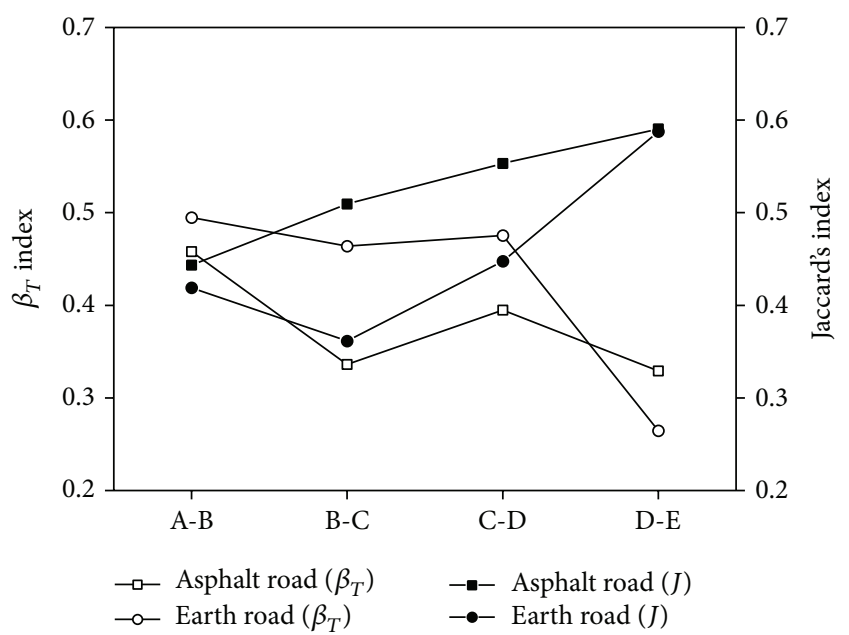

FIGURE 5: Characteristic of $\beta_{T}$ index and Jaccard's coefficient in plots of the asphalt roadsides and earth roadsides. A: plant communities in plots of 0-5 $\mathrm{m}$ to road verge; B: plant communities in plots of 5$10 \mathrm{~m}$ to road verge; $\mathrm{C}$ : plant communities in plots of $10-15 \mathrm{~m}$ to road verge; $\mathrm{D}$ : plant communities in plots of $15-20 \mathrm{~m}$ to road verge; $\mathrm{E}$ : plant communities in plots of $20-25 \mathrm{~m}$ to road verge.

the distance from study plot to roadside in the asphalt road verge. However, The Jaccard's coefficient of plant communities in the earth roadside decreased originally and then increased with the distance from study plots to earth roadside increasing (Figure 5). The values of the Jaccard's coefficient in the study plots adjacent to earth roadside were smaller than that adjacent to asphalt roadside within 20 meters from road verge (Figure 5). As soon as the distances of study plots to roadside were more than $20 \mathrm{~m}$, the values of the Jaccard's coefficient in the plots of earth roadside were approximate to that in the asphalt roadside (Figure 5). Our results indicated that both $\beta_{T}$ index and Jaccard's coefficient, which provide different but equally illuminating views of biodiversity $[63,64]$, were adopted in this study. The $\beta_{T}$ of plant communities in roadsidetended to decrease, while Jaccard's coefficient increased, with the distance increasing from sampling plots to road verge in asphalt roadsides (Figure 5). Some previous studies indicated that construction and maintenance of roads did a lot of negative effects to plant communities $[24,65,66]$ because most communities were destroyed during construction of roads, leaving few survival plants. The patterns of $\beta_{T}$ and Jaccard's coefficient indicated low ebb in plant communities within 5 to $15 \mathrm{~m}$ of earth roadsides (Figure 5). Actually, during investigation and sampling, the bare land and open water were the most common landscape types in 5 to $15 \mathrm{~m}$ away from earth in the YRD. While the sampling sites were more than $20 \mathrm{~m}$ away from road verges, the plant communities in both asphalt roadsides and earth roadsides indicated little differences.

\section{Conclusions}

The biodiversity of plant communities are deeply affected by roads in the YRD. The high plant species, especially exotics, was observed in the range of $0-20 \mathrm{~m}$ to the road verge. There were more plant species and exotics in the asphalt roadsides than that in the earth roadsides. However, the proportion of halophytes in plant communities in the earth roadsides was higher than that in the asphalt roadsides. The analysis results of $\beta$-diversity showed that there were more common species in the asphalt roadsides than that in the earth roadsides. The similarity of plant communities in studied plots of asphalt roadsides and earth roadsides increased with the increasing distance to road verge. The effected distance of roads on plant diversity was limited within $20 \mathrm{~m}$ to road verge. Our results indicate that the construction and maintenance of roads in wetland could increase the plant species diversities of communities and risk of alien species invasion.

\section{Conflict of Interests}

The authors declare that there is no conflict of interests regarding the publication of this paper.

\section{Authors' Contribution}

Yunzhao Li, Kai Ning, and Junbao Yu contributed equally to this work.

\section{Acknowledgments}

The authors are grateful for support from the Project of National Science \& Technology Pillar Program in "12th Five Year" period (2011BAC02B01 and 2012BAC19B08), the National Natural Science Foundation for Distinguished Young Scholar of Shandong Province (JQ201114), and the CAS/SAFEA international partnership program for creation research team. The authors thank the Yellow River Delta Ecology Research Station of Coastal Wetland, CAS, for the help in field work. 


\section{References}

[1] C. S. Findlay and J. Bourdages, "Response time of wetland biodiversity to road construction on adjacent lands," Conservation Biology, vol. 14, no. 1, pp. 86-94, 2000.

[2] F. S. Bernardino Jr. and G. H. Dalrymple, "Seasonal activity and road mortality of the snakes of the Pa-Hay-Okee wetlands of Everglades National Park, USA," Biological Conservation, vol. 62, no. 2, pp. 71-75, 1992.

[3] C. Scott Findlay and J. Houlahan, "Anthropogenic correlates of species richness in southeastern Ontario wetlands," Conservation Biology, vol. 11, no. 4, pp. 1000-1009, 1997.

[4] R. T. T. Forman and L. E. Alexander, "Roads and their major ecological effects," Annual Review of Ecology and Systematics, vol. 29, pp. 207-231, 1998.

[5] S. C. Trombulak and C. A. Frissell, "Review of ecological effects of roads on terrestrial and aquatic communities," Conservation Biology, vol. 14, no. 1, pp. 18-30, 2000.

[6] J. L. Frair, E. H. Merrill, H. L. Beyer, and J. M. Morales, "Thresholds in landscape connectivity and mortality risks in response to growing road networks," Journal of Applied Ecology, vol. 45, no. 5, pp. 1504-1513, 2008.

[7] R. E. Brock and D. A. Kelt, "Influence of roads on the endangered Stephens' kangaroo rat (Dipodomys stephensi): are dirt and gravel roads different?" Biological Conservation, vol. 118, no. 5, pp. 633-640, 2004.

[8] L. L. Kerley, J. M. Goodrich, D. G. Miquelle, E. N. Smirnov, H. B. Quigley, and M. G. Hornocker, "Effects of roads and human disturbance on Amur tigers," Conservation Biology, vol. 16, no. 1, pp. 97-108, 2002.

[9] A. Pauchard and P. B. Alaback, "Influence of elevation, land use, and landscape context on patterns of alien plant invasions along roadsides in protected areas of south-central Chile," Conservation Biology, vol. 18, no. 1, pp. 238-248, 2004.

[10] R. W. Tyser and C. A. Worley, "Alien flora in grasslands adjacent to road and trail corridors in Glacier National Park, Montana, (USA)," Conservation Biology, vol. 6, no. 2, pp. 253-262, 1992.

[11] L. A. Tigas, D. H. van Vuren, and R. M. Sauvajot, "Behavioral responses of bobcats and coyotes to habitat fragmentation and corridors in an urban environment," Biological Conservation, vol. 108, no. 3, pp. 299-306, 2002.

[12] R. L. Mumme, S. J. Schoech, G. E. Woolfenden, and J. W. Fitzpatrick, "Life and death in the fast lane: demographic consequences of road mortality in the Florida Scrub-Jay," Conservation Biology, vol. 14, no. 2, pp. 501-512, 2000.

[13] C. K. Dodd Jr., W. J. Barichivich, and L. L. Smith, "Effectiveness of a barrier wall and culverts in reducing wildlife mortality on a heavily traveled highway in Florida," Biological Conservation, vol. 118, no. 5, pp. 619-631, 2004.

[14] P. F. Develey and P. C. Stouffer, "Effects of roads on movements by understory birds in mixed-species flocks in Central Amazonian Brazil," Conservation Biology, vol. 15, no. 5, pp. 1416-1422, 2001.

[15] A. Seiler, "Ecological effects of roads: a review," Introductory Research Essay, vol. 9, pp. 1-40, 2001.

[16] M. Bhattacharya, R. B. Primack, and J. Gerwein, "Are roads and railroads barriers to bumblebee movement in a temperate suburban conservation area?" Biological Conservation, vol. 109, no. 1, pp. 37-45, 2002.

[17] B. Deckers, P. de Becker, O. Honnay, M. Hermy, and B. Muys, "Sunken roads as habitats for forest plant species in a dynamic agricultural landscape: effects of age and isolation," Journal of Biogeography, vol. 32, no. 1, pp. 99-109, 2005.

[18] I. F. Spellerberg, "Ecological effects of roads and traffic: a literature review," Global Ecology and Biogeography Letters, vol. 7, no. 5, pp. 317-333, 1998.

[19] Lyon, "Road effects and impacts on wildlife and fisheries," in Proceedings of the Forest Transportation Symposium, USDA Forest Service, Casper, Wyo, USA, 1985.

[20] R. Elvik, "To what extent can theory account for the findings of road safety evaluation studies?" Accident Analysis \& Prevention, vol. 36, no. 5, pp. 841-849, 2004.

[21] L. Ries, R. J. Fletcher Jr., J. Battin, and T. D. Sisk, "Ecological responses to habitat edges: mechanisms, models, and variability explained," Annual Review of Ecology, Evolution, and Systematics, vol. 35, pp. 491-522, 2004.

[22] A. E. Lugo and H. Gucinski, "Function, effects, and management of forest roads," Forest Ecology and Management, vol. 133, no. 3, pp. 249-262, 2000.

[23] J. A. Jones, F. J. Swanson, B. C. Wemple, and K. U. Snyder, "Effects of roads on hydrology, geomorphology, and disturbance patches in stream networks," Conservation Biology, vol. 14, no. 1, pp. 76-85, 2000.

[24] A. W. Coffin, "From roadkill to road ecology: a review of the ecological effects of roads," Journal of Transport Geography, vol. 15, no. 5, pp. 396-406, 2007.

[25] W. E. Rickard Jr. and J. Brown, "Effects of vehicles on arctic tundra," Environmental Conservation, vol. 1, no. 1, pp. 55-62, 1974.

[26] L. W. Carr and L. Fahrig, "Effect of road traffic on two amphibian species of differing vagility," Conservation Biology, vol. 15, no. 4, pp. 1071-1078, 2001.

[27] L. Fahrig, J. H. Pedlar, S. E. Pope, P. D. Taylor, and J. F. Wegner, "Effect of road traffic on amphibian density," Biological Conservation, vol. 73, no. 3, pp. 177-182, 1995.

[28] W. F. Laurance and G. Bruce Williamson, "Positive feedbacks among forest fragmentation, drought, and climate change in the Amazon," Conservation Biology, vol. 15, no. 6, pp. 1529-1535, 2001.

[29] T. Enoki, B. Kusumoto, S. Igarashi, and K. Tsuji, "Stand structure and plant species occurrence in forest edge habitat along different aged roads on Okinawa Island, southwestern Japan," Journal of Forest Research, vol. 19, no. 1, pp. 97-104, 2014.

[30] H. J. W. Vermeulen, "Corridor function of a road verge for dispersal of stenotopic heathland ground beetles Carabidae," Biological Conservation, vol. 69, no. 3, pp. 339-349, 1994.

[31] L. M. Cowardin and F. C. Golet, "US Fish and Wildlife Service 1979 wetland classification: a review," Vegetatio, vol. 118, no. 1-2, pp. 139-152, 1995.

[32] L. M. Cowardin, Classification of Wetlands and Deepwater Habitats of the US, Diane Publishing, Washing, DC, USA, 1979.

[33] S.-L. Zeng, T.-T. Zhang, Y. Gao et al., "Effects of road age and distance on plant biodiversity: a case study in the Yellow River Delta of China," Plant Ecology, vol. 212, no. 7, pp. 1213-1229, 2011.

[34] P. G. Angold, "The impact of a road upon adjacent heathland vegetation: effects on plant species composition," Journal of Applied Ecology, vol. 34, no. 2, pp. 409-417, 1997.

[35] T. Qin, Landscape Analysis of Yellow River Delta Based on Road Network-A Case Study of Dongying City, Shandong Agricultural University, Jinan, China, 2012.

[36] S. Godefroid and N. Koedam, "The impact of forest paths upon adjacent vegetation: effects of the path surfacing material 
on the species composition and soil compaction," Biological Conservation, vol. 119, no. 3, pp. 405-419, 2004.

[37] T.-W. Wang, C.-F. Cai, Z.-X. Li, Z.-H. Shi, and G.-H. Liu, "Simulation of distribution pattern of heavy metals in road verge soils using neural network; a case study of modern Yellow River Delta," Acta Ecologica Sinica, vol. 29, no. 6, pp. 3154-3162, 2009.

[38] C. Pagotto, N. Rémy, M. Legret, and P. Le Cloirec, "Heavy metal pollution of road dust and roadside soil near a major rural highway," Environmental Technology, vol. 22, no. 3, pp. 307-319, 2001.

[39] A. Christoforidis and N. Stamatis, "Heavy metal contamination in street dust and roadside soil along the major national road in Kavala's region, Greece," Geoderma, vol. 151, no. 3-4, pp. 257263, 2009.

[40] X. J. Zuo, D. F. Fu, and H. Li, "Variation characteristics of mercury in speciation during road runoff for different rainfall patterns," Clean: Soil, Air, Water, vol. 41, no. 1, pp. 69-73, 2013.

[41] N. A. Auerbach, M. D. Walker, and D. A. Walker, "Effects of roadside disturbance on substrate and vegetation properties in arctic tundra," Ecological Applications, vol. 7, no. 1, pp. 218-235, 1997.

[42] A. M. Truscott, S. C. F. Palmer, G. M. McGowan, J. N. Cape, and S. Smart, "Vegetation composition of roadside verges in Scotland: the effects of nitrogen deposition, disturbance and management," Environmental Pollution, vol. 136, no. 1, pp. 109$118,2005$.

[43] F.-Y. Wang, R.-J. Liu, X.-G. Lin, and J.-M. Zhou, "Arbuscular mycorrhizal status of wild plants in saline-alkaline soils of the Yellow River Delta," Mycorrhiza, vol. 14, no. 2, pp. 133-137, 2004.

[44] X. Zhang, S. Ye, P. Yin, and D. Chen, "Characters and successions of natural wetland vegetation in Yellow River Delta," Ecology and Environmental Sciences, vol. 18, no. 1, pp. 292-298, 2009.

[45] H. Fang, G. Liu, and M. Kearney, "Georelational analysis of soil type, soil salt content, landform, and land use in the Yellow River Delta, China," Environmental Management, vol. 35, no. 1, pp. 72-83, 2005.

[46] Y. Guan, G. Liu, and J. Wang, "Regionalization of salt-affected land for amelioration in the Yellow River Delta based on GIS," Acta Geographica Sinica, vol. 56, no. 2, pp. 198-205, 2001.

[47] C. Shi, L. You, B. Li, Z. Zhang, and O. Zhang, "Natural consolidation of deposits and its consequences at the Yellow River Delta," Scientia Geographica Sinica, vol. 23, no. 2, pp. 174181, 2003.

[48] R. H. Whittaker, "Evolution and measurement of species diversity," Taxon, vol. 21, pp. 213-251, 1972.

[49] M. V. Wilson and A. Shmida, "Measuring beta diversity with presence-absence data," Journal of Ecology, vol. 72, no. 3, pp. 1055-1064, 1984.

[50] R. Real and J. M. Vargas, “The probabilistic basis of Jaccard's index of similarity," Systematic Biology, vol. 45, no. 3, pp. 380385, 1996.

[51] R. Carver and J. G. Nash, Doing Data Analysis with SPSS: Version 18.0, Cengage Learning, Singapore, 2011.

[52] Z. Li, H. Wang, S. Liu, G. Song, and J. Gao, "Analysis about the biodiversity of Yellow River Delta," Ecology and Environment, vol. 15, no. 3, pp. 577-582, 2006.

[53] S. Zhu, W. Wang, Y. Wang, and K. Shan, "Wetland restoration and biodiversity conservation in the Yellow River Delta Nature Reserve," Journal of Beijing Foresty University, vol. 33, no. 2, pp. $1-5,2011$.
[54] C. H. Greenberg, S. H. Crownover, and D. R. Gordon, "Roadside soils: a corridor for invasion of xeric scrub by nonindigenous plants," Natural Areas Journal, vol. 17, no. 2, pp. 99-109, 1997.

[55] P. M. Tikka, H. Högmander, and P. S. Koski, "Road and railway verges serve as dispersal corridors for grassland plants," Landscape Ecology, vol. 16, no. 7, pp. 659-666, 2001.

[56] J. L. Gelbard and J. Belnap, "Roads as conduits for exotic plant invasions in a semiarid landscape," Conservation Biology, vol. 17, no. 2, pp. 420-432, 2003.

[57] Q. Tang, G. F. Liang, X. L. Lu, and S. Y. Ding, "Effects of corridor networks on plant species composition and diversity in an intensive agriculture landscape," Chinese Geographical Science, vol. 24, no. 1, pp. 93-103, 2014.

[58] W. M. Lonsdale and A. M. Lane, "Tourist vehicles as vectors of weed seeds in Kakadu National Park, Northern Australia," Biological Conservation, vol. 69, no. 3, pp. 277-283, 1994.

[59] S. L. Flory and K. Clay, "Invasive shrub distribution varies with distance to roads and stand age in eastern deciduous forests in Indiana, USA," Plant Ecology, vol. 184, no. 1, pp. 131-141, 2006.

[60] S. F. McCracken and M. R. J. Forstner, "Oil Road effects on the anuran community of a high canopy Tank Bromeliad (Aechmea zebrina) in the upper Amazon Basin, Ecuador," PLoS ONE, vol. 9, no. 1, Article ID e85470, 2014.

[61] R. Z. Watkins, J. Chen, J. Pickens, and K. D. Brosofske, "Effects of forest roads on understory plants in a managed hardwood landscape," Conservation Biology, vol. 17, no. 2, pp. 411-419, 2003.

[62] L. A. Parendes and J. A. Jones, "Role of light availability and dispersal in exotic plant invasion along roads and streams in the H.J. Andrews Experimental Forest, Oregon," Conservation Biology, vol. 14, no. 1, pp. 64-75, 2000.

[63] C. A. Lozupone, M. Hamady, S. T. Kelley, and R. Knight, "Quantitative and qualitative $\beta$ diversity measures lead to different insights into factors that structure microbial communities," Applied and Environmental Microbiology, vol. 73, no. 5, pp. 15761585, 2007.

[64] G. Stirling and B. Wilsey, "Empirical relationships between species richness, evenness, and proportional diversity," American Naturalist, vol. 158, no. 3, pp. 286-299, 2001.

[65] I. Keller, W. Nentwig, and C. R. Largiadèr, "Recent habitat fragmentation due to roads can lead to significant genetic differentiation in an abundant flightless ground beetle," Molecular Ecology, vol. 13, no. 10, pp. 2983-2994, 2004.

[66] J. L. Gelbard and S. Harrison, "Roadless habitats as refuges for native grasslands: interactions with soil, aspect, and grazing," Ecological Applications, vol. 13, no. 2, pp. 404-415, 2003. 

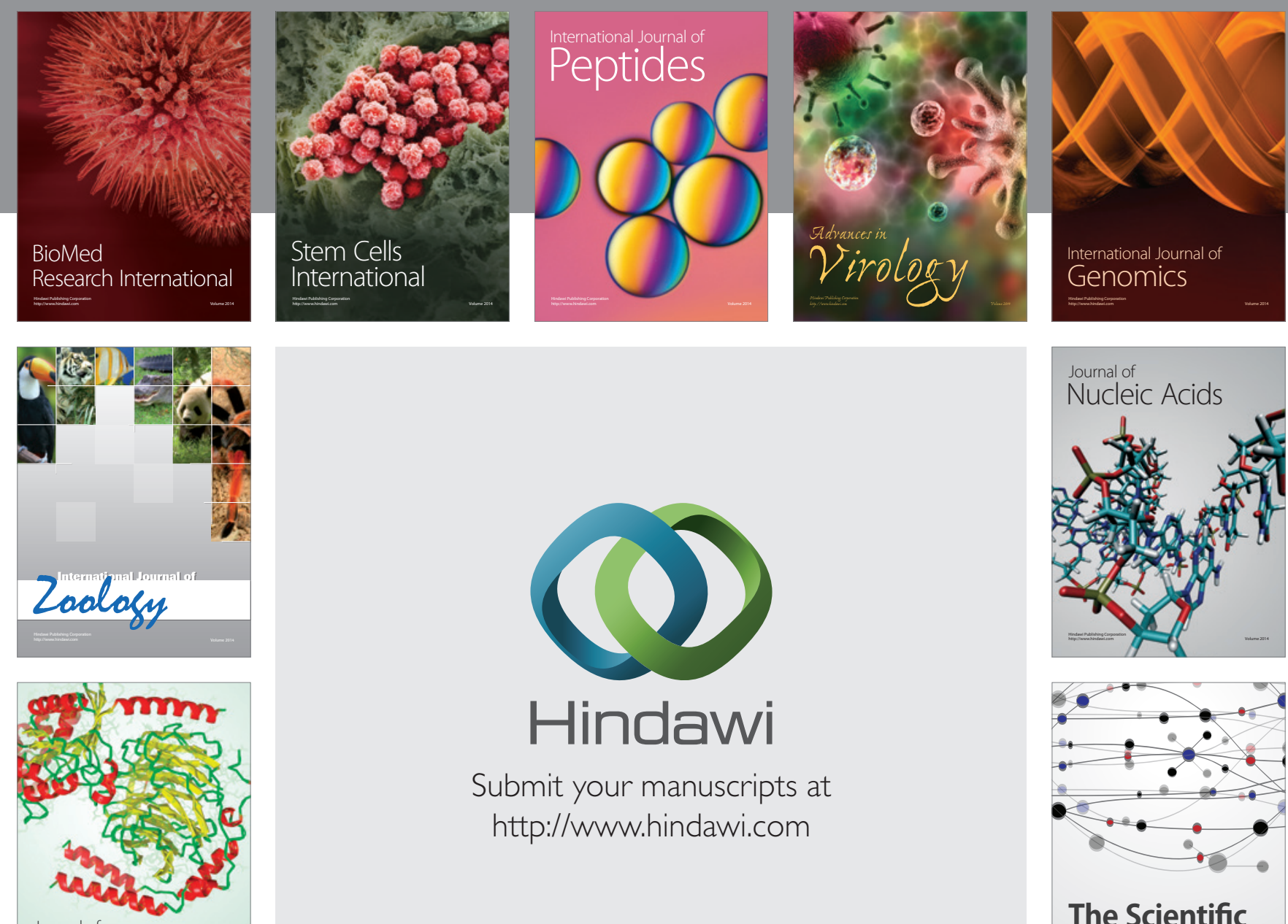

Submit your manuscripts at

http://www.hindawi.com

Journal of
Signal Transduction
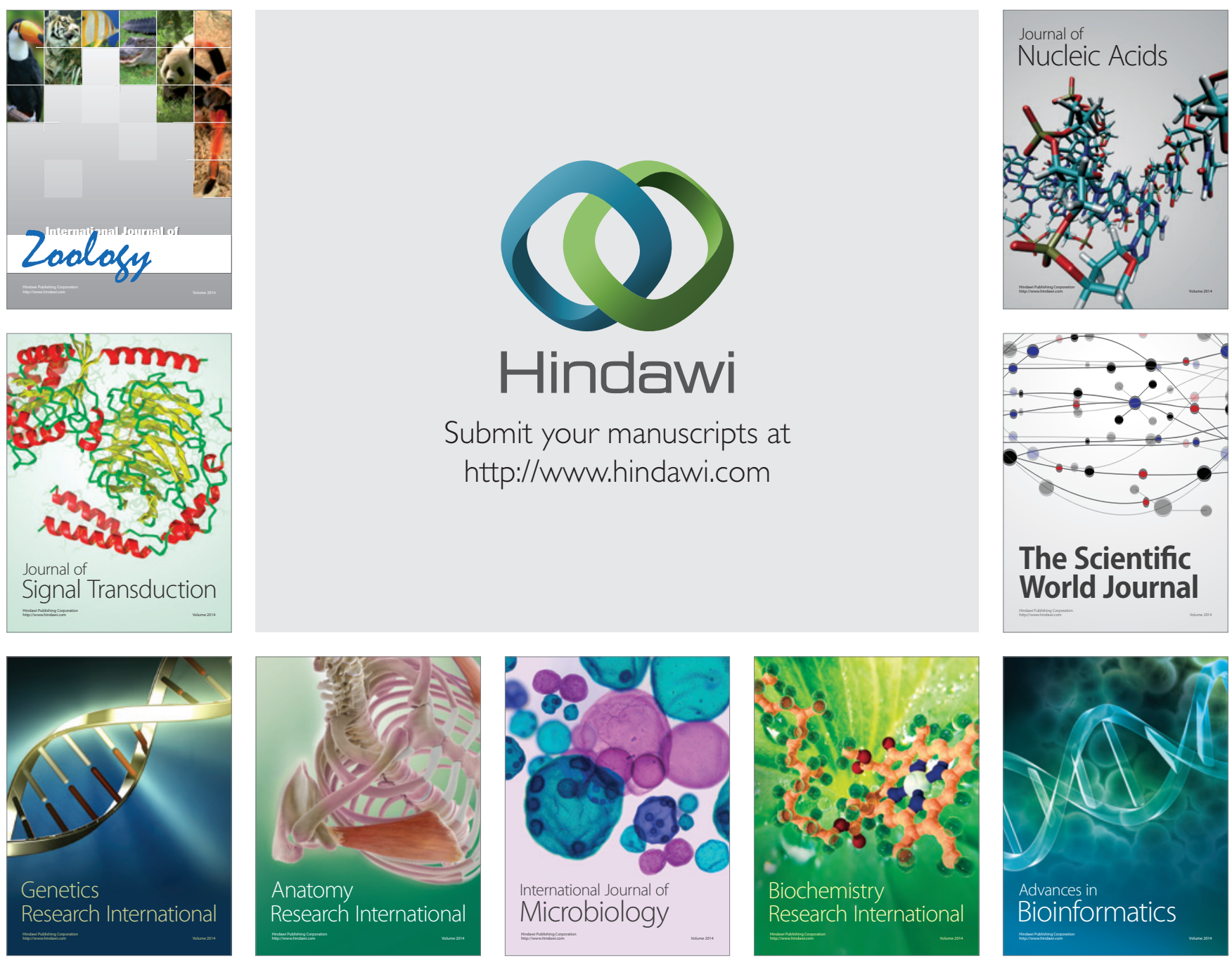

The Scientific World Journal
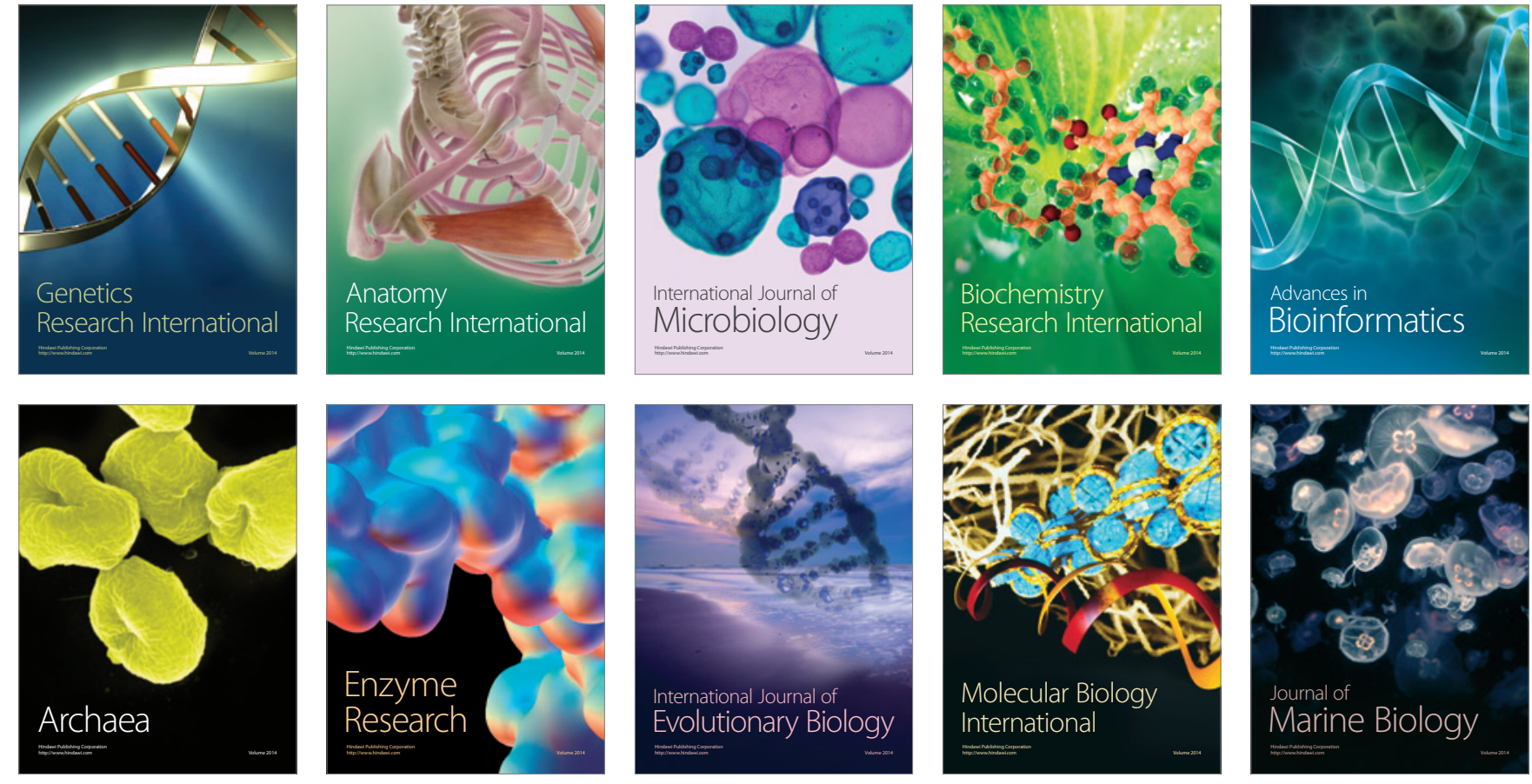